\title{
Latest Developments in Sustainable Water Management
}

\author{
Ivan Halkijević \\ Damir Bekić \\ Goran Lončar \\ Kristina Potočki \\ Gordon Gilja \\ Dalibor Carević
}

Ivan Halkijević, Damir Bekić, Goran Lončar, Kristina Potočki,

Gordon Gilja, Dalibor Carević

University of Zagreb, Faculty of Civil Engineering, Croatia

Corresponding author: Ivan Halkijevic, halkijevic@agrad.hr

https://doi.org/10.5592/CO/FTCE.2019.07 


\section{Latest Developments in Sustainable Water Management}

\section{Abstract}

An overview of new and upcoming approaches (technologies, techniques, methodologies, tools, etc.) in various aspects and areas of water management is given in the paper. A brief account of the application and limitations of remote sensing techniques in monitoring meteorological and hydrological data, in efficient irrigation planning, and in improvement of water use in agriculture, is also provided. Several new water treatment technologies with a large-scale application potential are presented, and the use of numerical modelling in water treatment, 'green' infrastructure, and coastal engineering planning and design, is outlined. Such novel approaches are increasingly used in various water management activities, with an ultimate goal of achieving water management sustainability, which will surely contribute to the longevity of mankind.

Key words: remote sensing, geospatial technology, advanced water treatment, numerical modelling, green infrastructure, coastal engineering

\section{Najnovija dostignuća u održivom gospodarenju vodama}

\section{Sažetak}

Ovaj rad daje pregled novih i nadolazećih pristupa (tehnologija, tehnika, metodologija, alata itd.) u različitim aspektima i područjima gospodarenja vodama. Prikazan je pregled primjene i ograničenja tehnika daljinskih opažanja u praćenju meteoroloških i hidroloških podataka, učinkovitom planiranju navodnjavanja i poboljšanju upotrebe vode u poljoprivredi. Predstavljeno je nekoliko novih tehnologija za pročišćavanje vode s potencijalom za primjenu u stvarnim uvjetima količina i kakvoća otpadnih voda, zajedno s korištenjem numeričkog modeliranja u pročišćavanju voda, implementaciji objekata "zelene" odvodnje te planiranju i projektiranju u obalnom inženjerstvu. Ovakvi novi pristupi sve su češći u raznim aktivnostima gospodarenja vodama, a s konačnim ciljem postizanja održivog stanja gospodarenja vodama koje će zasigurno pridonijeti dugovječnosti čovječanstva.

Ključne riječi: daljinsko opažanje, geoprostorna tehnologija, napredne metode pročišćavanja voda, numeričko modeliranje, zelena odvodnja, obalno inženjerstvo 


\section{Introduction}

Humans are increasingly becoming aware that the longevity of water usage can only be achieved by meeting our current needs for water without endangering capabilities of future generations to meet their own needs, for an unlimited period of time. This concept, known as sustainability, includes at least three interrelated components: environment, society, and economy. When dealing with a specific water management problem, it is possible that other inherent characteristics, for example technical or political components, will have to be involved as well [I], [2], [3]).

Water management sustainability is achieved through the effectiveness of each sustainability component. This effectiveness is achieved by maximizing the efficiency of positively perceived processes (aspects) and by minimizing negatively perceived processes within each component. For this, all processes (e.g. in basins, agriculture, wastewater drainage and treatment systems, etc.) must be known and analysed so that their efficiency can be evaluated.

Evaluating and improving efficiency of a process involves the use of a wide variety of approaches (technologies, techniques, methodologies, methods, procedures, tools, measuring equipment, software, etc.), a general goal being to meet all particular social needs and, at the same time, not to compromise the integrity of the ecosystem, or the integrity of the hydrological cycle. This is, of course, extremely difficult since all processes in the ecosystem are not entirely understood or known. Thus, it is not possible to grasp the overall human impact on the ecosystem and to be sure in the preservation of its integrity. But this ultimate and desirable goal can be identified as a sustainable state and, hence, the final stage of the sustainable development process. During the process of sustainable development, all these above-mentioned approaches (techniques, methods, tools, etc.), go through stages of their own development and are being improved so as to increasingly contribute to the sustainability in the sphere of water management. Thus, this paper gives an overview of new and upcoming approaches used in the design and improvement of various water management areas, such as drinking water/wastewater treatment and drainage, agriculture, and coastal engineering. An overview of new remote sensing techniques for monitoring meteorological and hydrological variables and ground cover is also provided.

\section{New and upcoming approaches and techniques in water manageent}

\subsection{Trends in application of remote sensing in hydroscience and engineering}

In recent decades, remote sensing has become a valuable data source for spacetime investigations of various geophysical phenomena on the land and sea alike. By covering large areas, remote investigations allow for point information from weather/ hydrological/marine gauges to be complemented and extended at different scales in both space and time. Remote investigation is based on sensing the earth's surface 
with various active or passive sensors of different types and frequencies of energy spectra. The area of remote sensing is still under significant development (sensors, data transmission, new parameters) and so the information from gauge stations is still necessary for the calibration/verification of remote sensing measurements, and for the validation and testing of new procedures and algorithms.

Remote sensing via aerial and space-borne platforms has been extensively used to supplement point information in the land and water resources analysis at different stages in watershed planning and management. Mapping of water boundaries, elevation model development, land cover identification and monitoring, snow and ice cover mapping, evapotranspiration and soil moisture mapping, precipitation measurement, water yield and soil erosion estimation, are some of the areas in which remote sensing techniques have been extensively utilised.

\section{I.I.Water Body Mapping}

Remote sensing information in hydroscience is directly used in the identification and mapping of the surface water bodies. A fine spatial resolution is required in order to achieve accurate mapping of water boundaries. Appropriate optical remote sensing techniques have extensively been used in this respect. Many satellite-borne missions (Landsat, MODIS, QuickBird, Ikonos, SPOT, RADARSAT, Sentinel, ASTER) provide a free access to raw images and products of global coverage since their initial missions in 1984.

Water surface can easily be differentiated from the land and vegetation as it adsorbs most of the energy in near-infrared (NIR) and mid-Infrared (MIR) wavelengths and gives darker tones in the bands [4]. Figure I shows Peruća Lake in different bands of the Sentinel-2A images for two different water level stages. Approximately $10 \mathrm{~m}$ spatial resolution zones show the lake for the single band images $(B I=443 \mathrm{~nm}, \mathrm{~B} 5$ $=705 \mathrm{~nm}$ ) and for composite images: true colour (B2, B3, B4), false colour (B3, B4, B8) and NDWI (Normalized Difference Water Index). The contrast between water and other pixels is poor in the VIS band (BI, Figure Iba), but is much sharper in the $\mathrm{IR}$ region ( $\mathrm{B} 5$, Figure $\mathrm{Ibb})$. The water boundary can be distinguished with ease in the composite band images (false colour, Figure I cb).

The NDWI is the most appropriate parameter for water body mapping [4]. It is obtained from NDWI = (B3-B8)/(B3+B8) by using the green and near infra-red bands. A comparison of NDWI zones (Figure Ibc and Figure Icc) clearly shows water body changes at two different water stages of Peruća Lake. 

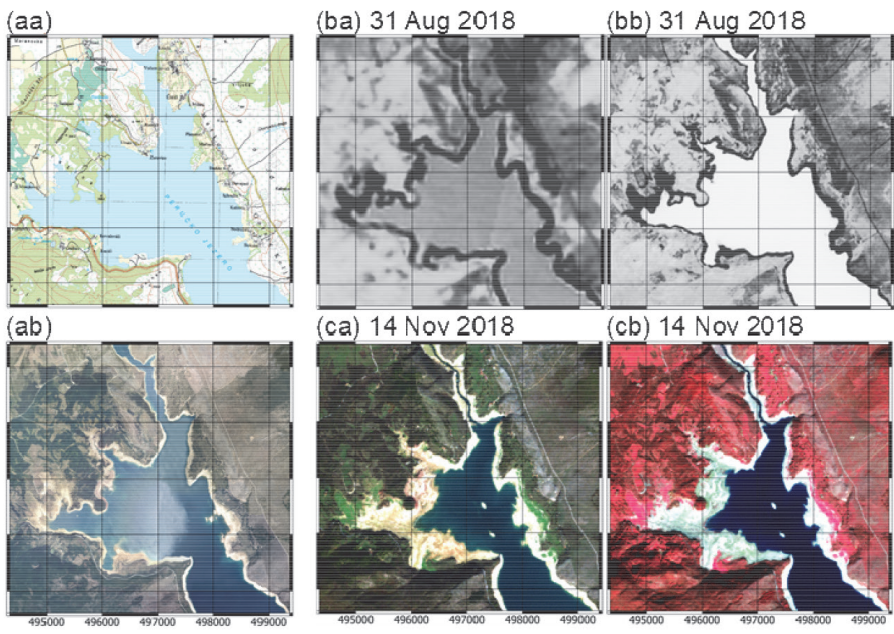

(bc) 31 Aug 2018

(ca) 14 Nov 2018

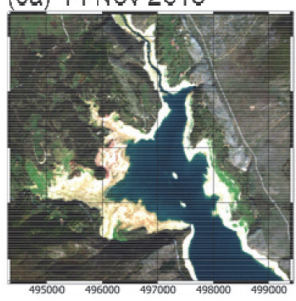

(cb) 14 Nov 2018

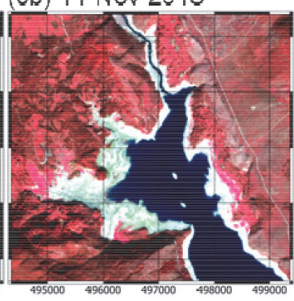

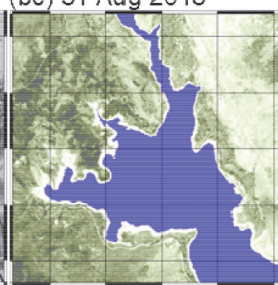

(cc) 14 Nov 2018

Figure I. Sentinel-2A images of Peruča Lake in different spectral bands for two different water level stages: layout (aa-base map 25k, ab-ortophotographic chart); images at normal water level 3 I Aug 2018 (ba-band I, bb-band 5, bc-NDWI); images at low water level 14 Nov 2018 (ca-true colour, cbfalse colour, cc-NDWI)

Optical sensors can be used during daytime only, and they exhibit limited capabilities of penetration through clouds and thick vegetation. Their applicability is thus limited to fair weather conditions at daytime. These limitations can partly be overcome by active microwave sensors (such as Real Aperture Radar or Synthetic Aperture Radar $(\mathrm{SAR})$ ). Moreover, water surface provides a high reflection at microwave energy spectra, and SAR images have high potential for water body delineation in all-weather conditions. SAR images can be applied in historical investigations of water bodies but also in the real-time monitoring of extreme hydrological events and in the operational flood forecasting systems as feedback control information in numerical models.

\subsubsection{Digital elevation models}

Satellite and airborne remote investigations have been extensively used for developing the Digital Elevation Model (DEM) of river basins by using stereoscopic attribute of images. Besides development of elevation model, the information from DEM has been used in hydrological and hydraulic modelling for extraction of drainage paths, delineation of catchment boundary, aspect detection of catchments and channels, etc. There are several open-access Digital Surface Model (DSM) datasets of global coverage at a $30 \mathrm{~m}$ horizontal resolution, such as SRTM, ASTER, or AW3D30.

The main limitation of DEM from stereoscopic photographs is its vertical accuracy, which may be increased to some extend in post-processing. The Light Detection And Ranging (LiDAR) survey may significantly improve horizontal resolution and vertical 
accuracy of DEMs, providing horizontal and vertical resolution of DEM of less than I $\mathrm{m}$ and $0.2 \mathrm{~m}$, respectively, in river basins and floodplains [5].

A comparison of LiDAR and geodetic RTK-GPS surveys of the dyke crest along the Drava River near Varaždin (Croatia) is shown in Figure 2. Detailed geodetic RTKGPS and LiDAR surveys were made available in 2015/2016 for a $3550 \mathrm{~m}$ long floodprotection dyke on the Drava River.The LiDAR survey included sub-meter horizontal points (Figure $2 \mathrm{~b}$ ) from which a $1.0 \mathrm{~m}$ resolution DEM was developed (Figure $2 \mathrm{c}$ ). The elevation profiles of two surveys along the dyke crest are shown (in [m a.s.l]) together with deviations of LiDAR to RTK-GPS survey (Figure 2d). The statistics of deviations of DEM from LiDAR to RTK-GPS survey, for 77 points along a $3550 \mathrm{~m}$ long embankment crest, shows the low mean error (ME) of LiDAR survey of $-0.08 \mathrm{~m}$ and the low standard deviation of $0.04 \mathrm{~m}$. High vertical precision of LiDAR survey and subsequent DEM can lead to significant improvements of hydrological/hydraulic models and in the mapping of flood-prone areas [6], as compared to traditional survey techniques and DEM derived from stereoscopic satellite images.
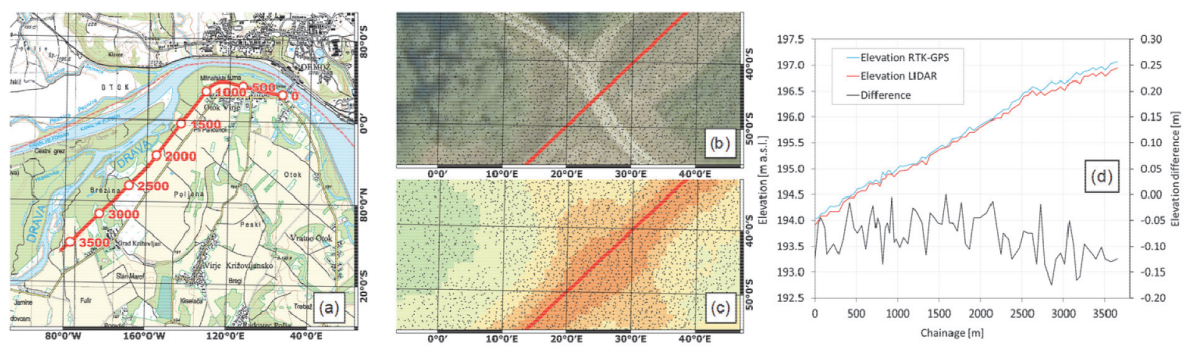

Figure 2. Surveys of flood-protection dyke on the Drava River near Varaždin, (a) layout with dyke chainages, (b) ortophotographic chart with LiDAR survey points, (c) DEM from LiDAR survey, (d) dyke crest elevation profiles from LiDAR and RTK-GPS surveys with elevation difference of LiDAR to RTK-GPS survey

\section{I.3. Evaluation of actual evapotranspiration}

Actual evapotranspiration (ET) is the most complicated water flux component that can be estimated in a river basin. Actual ET can be indirectly estimated from the formulation of energy balance of earth surface by using visible and thermal bands of sensors. The instantaneous latent heat flux of ET is calculated as a residual of the energy balance, which is then converted into daily ET by various methods: SEBAL, METRIC, TSEB, S-SEBI, SEBS etc. The remote sensing based ET can be estimated at a high spatial resolution (up to $30 \mathrm{~m}$ ) but it this sensing is limited to clear sky conditions and days of satellite overpass. Several approaches have been proposed to improve temporal resolution: a combination of satellite images from two different platforms, an integration of satellite images into hydrological modelling, and a combination of evaporative fraction and point daily PET. 
The evaluation of ET via remote sensing depends on the availability and quality of images. The analysis of satellite images from Landsat 7 ETM+ (Enhanced Thematic Mapper Plus) mission for the Krapina River basin in Croatia revealed that only 26 images were usable in the 1999-2003 period [7]. In this period, direct measurements of ET were available at two lysimeter stations around the Krapina River basin:ZagrebMaksimir agro-ecological station (available in 1990-1999) and Varkom-Varaždin infiltrometer station (available in 1988-2002) (see Figure 3a).

The SEBAL approach was implemented for estimating the actual ET in the Krapina River basin in the period from April 1999 to June 2003. The advantages of SEBAL approach include an automatic internal calibration within each analysed image (assumptions on the energy balance state are made at the hottest and the coolest pixel in the image) and minimum auxiliary ground-based data [8]. The results of SEBAL ET estimates ( $E T_{\text {SEB }}$ ) were compared to the daily ET measurements (ET $T_{\text {LYS }}$ ) at Varkom-Varaždin and Zagreb-Maksimir lysimeters (see Figure 3b). Differences between SEBAL ET estimates and ET measurements at gauging stations are within the $0.0-1.0 \mathrm{~mm}$ range and have the average MAE $=0.3 \mathrm{~mm}$ (mean absolute error), $\sigma=0.44 \mathrm{~mm}$ (st.dev) and NSE $=0.64$. This confirms high reliability of the SEBAL method for the evaluation of daily ET estimates.
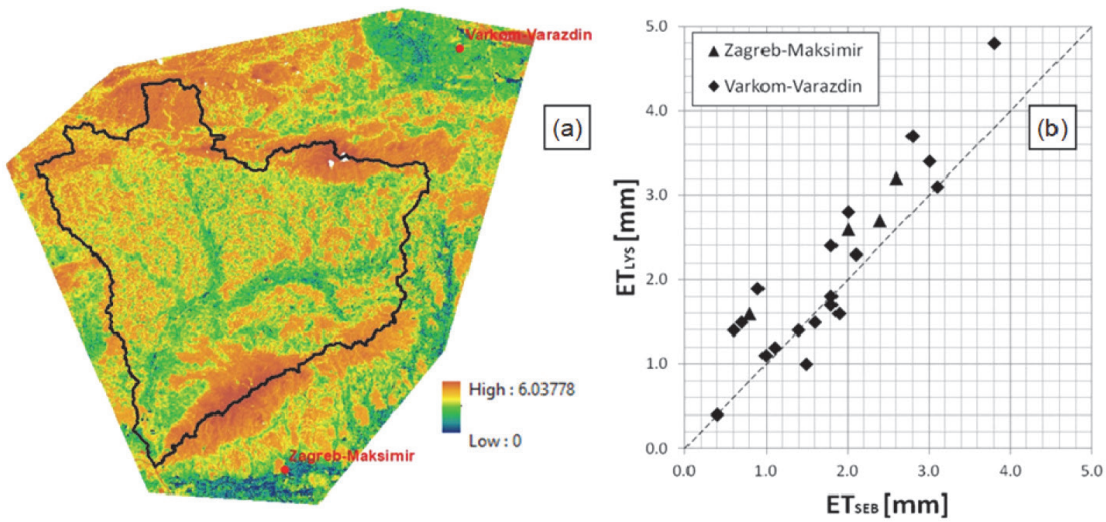

Figure 3. Distribution of SEBAL ET estimates $\left(\mathrm{mm} \mathrm{day}^{-1}\right)$ for 6 June 2000 in the Krapina River basin (a) and comparison of SEBAL ET estimates $\left(\right.$ ET $_{\mathrm{SEB}}$ ) to measured daily ET values at Varkom-Varaždin and Zagreb-Maksimir

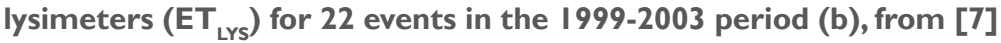

\subsection{Geospatial technology in agriculture}

Water is the most essential component of agricultural systems, and the latter are the largest consumers of water resources worldwide. Freshwater abstraction for agriculture accounts to up to $70 \%$ on an average globally, while this figure is $33 \%$ 
for Europe, $80 \%$ for southern Europe and up to $90 \%$ for developing countries [9], [I0], [II]. Population growth has led to intensification of agricultural activities worldwide, with a sixfold increase in irrigated areas [12]. Conventional projection of exploitation of water resources by 2050 predicts an increase of $53 \%$ in order to keep up with the food demand [13], while additional 15\% of fresh water would be allocated from agriculture to households and industry [14].An increase in freshwater consumption can lead to greater vulnerability of agriculture through soil salinization and deterioration of related ecosystems [15].

Agricultural irrigation contributes to water stress because its efficiency is relatively low, with only $55 \%$ to $65 \%$ of the water delivered to crop being actually used by it. In order to satisfy growing demands for greater crop production, irrigation needs to be sustainable as highlighted in the Water Framework Directive. Over-irrigation does not generally cause reduction in crop yield, and is therefore more often than not excessively applied to crops. In turn, over-irrigation can cause reduction in water supply to competing users, water-logging conditions for the crop and nutrient loss [14]. More than one-third of the irrigated land is affected by land salinization or rising groundwater level problems as a result of over-irrigation and poor drainage [16], and it is a key issue that needs to be addressed in sustainable farm production [17].

Sustainable irrigation, i.e. a higher crop production using less water resources, can be achieved from the engineering perspective by scheduling water application for irrigation and developing methods associated with it in order to keep it commercially competitive [12]. Irrigation frequency depends on many parameters like soil moisture, weather conditions, water allocation, crop growth stage, and its sensitivity to water stress. A major research goal is to develop techniques and methods for maximising crop yield with minimum water consumption, while at the same time minimizing water losses primarily through evaporation and percolation [14]. The achievement of this goal is dependent on understanding how much water is used by the crops in specific conditions arising from soil characteristics, soil fertility, soil moisture, canopy volume, water content, and biotic and abiotic stress [18].

Important data for efficient irrigation scheduling, or precision irrigation, can be acquired by discrete or continuous monitoring of relevant parameters. Remote sensing via satellite, and airborne and unmanned aerial vehicles, equipped with related sensors, can be used for this purpose [18], [19]. Spectral signatures of all surfaces and objects in the monitored area can be collected with remote sensing, resulting in image data with specific spatial resolution [20]. Various sensors can be utilized to capture remotely sensed vegetation indices for precision irrigation and estimation of crop water status, evapotranspiration, infrared thermography, and soil and crop characteristics [17]. Remote sensing applications can be more effective if they combine data from multiple sensors to complement each other for an improved extraction of information in irrigated settings [2I].

In order to improve the efficiency of water use in agricultural management, it is first necessary to calculate water requirement for irrigation needs form estimated crop water requirements and soil water balance, where crop evapotranspiration is the main component. Multispectral imagery of canopy reflectance and reference 
evapotranspiration can be directly converted into maps of potential crop water use [22], [23]. Hadjimitsis et al. [19] have presented methodology for monitoring agricultural areas and estimating irrigation demand using satellite remote sensing, irrigation models, and spectroradiometric measurements. They used satellite images to define the vegetation index, surface albedo and temperature in the monitored area. Spectral signature of crops was measured with sun-photometers and spectroradiometers. Crop water parameters, i.e. spatial variations of actual evapotranspiration, were estimated with the remote sensing algorithm Surface Energy Balance Algorithm for Land and Surface Energy Balance System. The results demonstrated potential of the remote sensing method and water balance models to determine spatial variations of actual evapotranspiration for an agricultural area, using data from any available satellite source at different scales, but complemented with routine meteorological measurement of air temperature, humidity, wind speed and sunshine duration. Tazekrit et al. [23] showed that the demand of pumped irrigation water can be estimated from satellite images using the SAtellite Monitoring of Irrigation Model (SAMIR). Calculated volumes compared with measured data of pumped irrigation water for single year period show the difference of less than $10 \%$. One of useful tools for agricultural decision support system is the dynamic remote sensing of land affected by salinity and water-logging. Dehni and Lounis [24] have successfully mapped surface indices of salinity and sodicity in IDRISI GIS software using multi-spectral optical data from the LANDSAT Enhanced Thematic Mapper.The area affected by water-logging due to seepage and salinity due to salts on the surface was visually interpreted as visible white salt encrustation, while the Wetness Index was used to enhance the spectra of wet soil. The developed method has proven to be an efficient analytical tool in pattern recognition of highly saline areas using the geo-statistical modelling over soil electrical conductivity data.

Corbari et al. [25] investigated advances in coupling satellite driven soil water balance model and meteorological forecast as support for precision irrigation. They showed that it is possible to get reliable soil moisture forecasts for up to three days, which can be used in the irrigation scheduling process. This data can reliably be used only if the water stress threshold that regulates the irrigation timing can reliably be determined. The use of climatic models for meteorological forecast enables compensation for future climate change scenarios, where supervised learning can be applied for solving problems related to water availability [26]. Water stress can reduce and remove specific spectral properties of the crop through e.g. lowering of the red light absorbance [27]. Masseroni et al. investigated the reliability of thermal and optical indices derived from imaging techniques for detecting the crop water status. Their findings confirmed the previous findings that thermal data (primarily the CropWater Stress Index) are a reliable indicator of the crop water status, as well as the optical Photochemical Reflectance Index, while the Normalized Difference Vegetation Index may be a valuable index for the assessment of severe water stress conditions. They concluded that the two indices can be considered as valid alternative to conventional methods to support the irrigation management useful for open field applications, in particular for the improvement of irrigation scheduling. 
Liu et al. [28] evaluated the capability of different datasets for soil drainage mapping in agricultural fields. The evaluated datasets include apparent soil electrical conductivity, remotely sensed high-resolution airborne hyperspectral reflectance, and C-band synthetic aperture radar backscattering coefficients, coupled with the high precision digital elevation model. The study showed that the in-field soil drainage could be effectively mapped using the high-resolution optical and C-Band radar remote sensing data, and the apparent soil electrical conductivity data acquired under bare soil conditions. This potentially provides an alternative to the more traditional soil field survey, which usually requires more resources, especially to meet the requirements of precision agriculture. On the other hand, the proposed canonical analysis provides an opportunity to map soil drainage on a continuous basis, revealing the continuous variation of many soil conditions [28].Al-Saady et al. [29] also showed that the use of remotely sensed data (ASTER GDEM) and GIS techniques (ArcSWAT and other GIS tools) is more appropriate, precise, and economic for extracting drainage network and morphometric parameters of river basins, compared to traditional methods. GIS techniques are excellent tools for hydrologic analyses of drainage networks and for the high-accuracy drainage basin mapping [29], [30].

\subsection{Advanced water and wastewater treatment technologies}

The disinfection with chlorine or chlorine based compounds is the most common treatment for the disinfection of drinking water. However, chlorinated hydrocarbons (such as trihalomethanes, chloroform, dichloromethane) and nitrosamines, which may be highly cancerous, are produced as by-products in the reaction of chlorine and organic compounds. The accumulation of these by-products, along with the accumulation of heavy metals in human body, increases the risk of cancer and cancer related diseases [3I], [32], [33].

According to present research, some treatment technologies, such as the advanced oxidation methods and electrochemical methods, show the possibility for efficient removal of different contaminates in the water purification process.

Advanced oxidation processes (AOP) are procedures of water treatment in which the molecules of water, under the influence of chemical, electrical, mechanical or radiation energy, are disrupted to hydrogen ions and highly reactive free radicals (such as hydroxyl radicals $(\cdot \mathrm{OH})$ ) which, due to their electron-induced instability (one or more unpaired electrons), react with other substances in water. Among various radicals (superoxide radical, hydroperoxyl radical, alkoxyl radical, perhydroxyl radical), the hydroxyl radical $(\cdot \mathrm{OH})$ is the most important for water/wastewater treatment due to its high standard potential (the affinity to gain or lose electrons in a chemical reaction). Hydroxyl radical is short living, nonselective and can oxidize and decompose numerous hazardous compounds to $\mathrm{CO}_{2}$ and inorganic ions [34]. 
There are several different mechanisms for the formation of this radical. They are usually divided into three main categories:

- chemical-based processes that use oxidizing chemicals and reactive radicals: ozonolysis $\left(\mathrm{O}_{3}\right)$ and Fenton's oxidation (hydrogen peroxide $\left(\mathrm{H}_{2} \mathrm{O}_{2}\right)$ and ferrous iron as catalysts).

- wave energy-based processes: photolysis (ultraviolet (UV) as catalyst), photocatalysis (UV and titanium dioxide $\left(\mathrm{TiO}_{2}\right.$ ) as catalyst), $\mathrm{UV} / \mathrm{H}_{2} \mathrm{O}_{2}$ processes, sonolysis (ultrasound (US) as catalyst), and microwave processes.

- combined advanced oxidation processes: sonophotolysis (UV/US), sonophotocatalysis (UV/US/ $\left.\mathrm{TiO}_{2}\right)$, UV/ozone processes, UV/Fenton processes, and US/Fenton processes.

Photocatalytic processes with $\mathrm{TiO}_{2}$ are most widely studied due to its high removal efficiencies, potential to absorb solar energy and as it is stable and non-toxic. The current research area of photocatalysis includes the optimization of processes for higher efficiency, the research of visible-light sensitive process and the combination of other AOPs. However, the large-scale applications and continuous photocatalytic processes are still missing [35].

\subsection{Ultrasonic water treatment}

Recently, research is also focused on ultrasound technology, which is based on mechanical wave energy for water/wastewater treatment. High-intensity ultrasound, due to the acoustic cavitation phenomena, induces various sonochemical/ sonophysical effects without the use of chemicals. This gives a potential for novel and environmentally friendly water treatment processes.

Ultrasound occurs when the frequency of a sound wave is greater than $18-20 \mathrm{kHz}$. When ultrasound is present in aqueous phase, a sound energy field is created due to sound pressure, causing water molecules to vibrate at their mean position. The sound pressure changes sinusoidally resulting in periodic repetition of the compression phase (the pressure is positive) and the rarefaction phase (the pressure is negative). Water molecules are drawn apart in the low pressure phase, in which water evaporates and cavitation bubbles are formed, while at high pressure these cavitation bubbles violently collapse, Figure 4. Bubbles are usually formed at the surface of suspended solids in water or on the reactor walls during the rarefaction phase. During the periodical change of pressure, bubbles pulsate with the diameter increasing at the rarefaction phase and decreasing when the pressure increases. Bubbles increase in size since the dissolved gas and vaporized water enter the bubbles during the rarefaction phase and then liquefy during the compression phase. When a bubble reaches a critical size or collides with another bubble, it collapses when the pressure increases. In such conditions, compression occurs adiabatically and the gas and vapour are compressed at a very high temperature (around $4000^{\circ} \mathrm{C}$ and 500 bars) causing the inside of the bubble to transform into a plasma state [36]. Bubble formation, growth and implosion with the action of ultrasound in the liquid is called acoustic cavitation. 


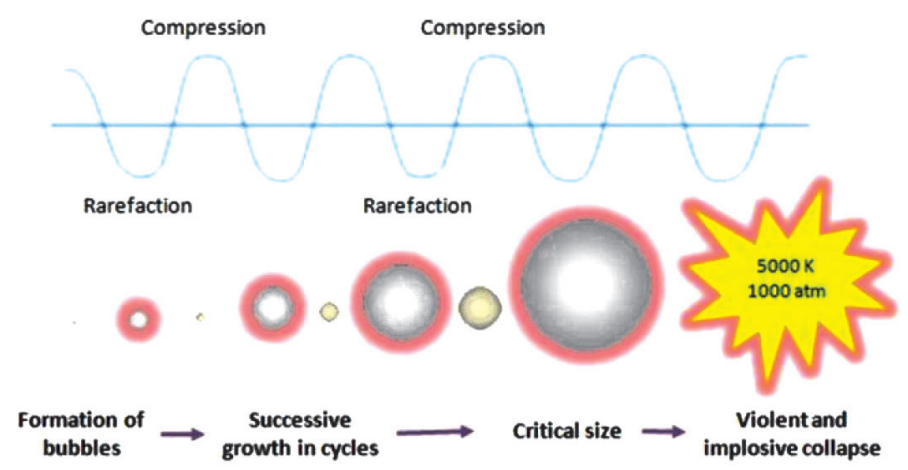

Figure 4. Formation, growth and implosion of a cavitation bubble [37]

These extreme conditions result in chemical reactivity and the formation of hydroxyl, hydrogen, and oxygen radicals. These radicals react in different ways in the final phase of the collapse (hot spot chemistry), cause fast oxidation of organic and inorganic matter and the degradation of complex compounds in water [38]. Main reactions involve combinations of radicals and reactions with vaporized molecules:

$\mathrm{H}_{2} \mathrm{O} \rightarrow \mathrm{OH}+\mathrm{H}$

$\mathrm{O}_{2} \rightarrow 2 \mathrm{O}$

$\mathrm{H}+\mathrm{H} \rightarrow \mathrm{H}_{2}$

$\mathrm{H}+\mathrm{OH} \rightarrow \mathrm{H}_{2} \mathrm{O}$

$\mathrm{O}+\mathrm{H}_{2} \mathrm{O} \rightarrow 2 \cdot \mathrm{OH}$

$\mathrm{H}+\mathrm{O}_{2} \rightarrow \cdot \mathrm{OH}+\mathrm{O}$

$\mathrm{OH}+\mathrm{OH} \rightarrow \mathrm{O}+\mathrm{H}_{2} \mathrm{O}$

Inside the cavitation bubble water molecules are pyrolysed forming $\mathrm{OH}$ and $\mathrm{H}$ radicals according to the reactions (I) to (7). There are mainly three regions for chemical reactions: (a) a hot gaseous nucleus in which temperature and pressure are extremely high, (b) an interfacial region with radical gradient in temperature and local radical density, and (c) a bulk solution at ambient temperature [34]. Therefore, chemical effects of ultrasound do not occur in direct interaction with molecular species, but ultrasound chemistry (sonochemistry) primarily derives from acoustic cavitation that serves as an effective means for concentrating diffuse energy of the sound [39]. 
An ultrasonic transducer, Figure 5, is used to generate ultrasound. It converts the electrical signal into mechanical displacements of a certain crystalline material according to the inverse piezoelectric effect. The frequency of the signal corresponds to the frequency of the displacement and ultrasound occurs when a value of around $18-20 \mathrm{kHz}$ is reached.

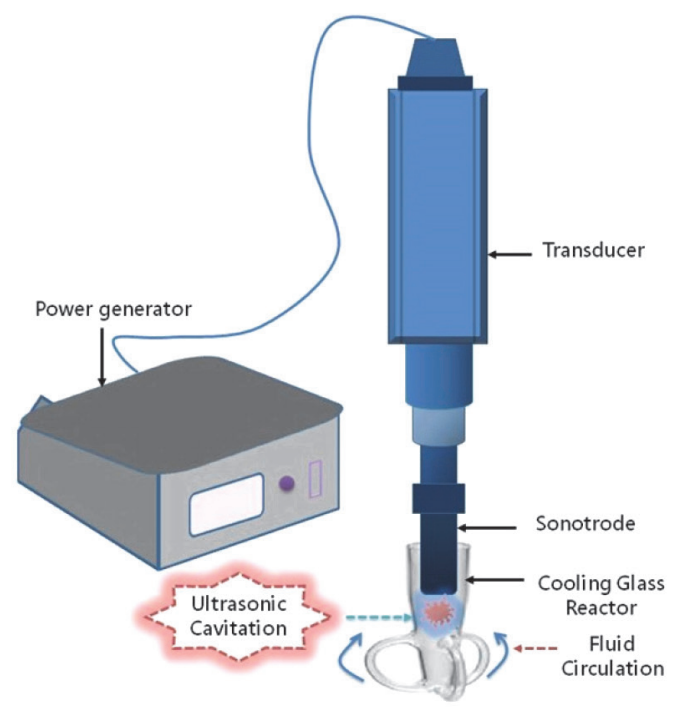

Figure 5. Basic elements of the ultrasonic device [34]

The ultrasonic removal of contaminant from water has three basic, practically simultaneous, mechanisms. Chemical mechanism is based on chemical reactions between the generated free $\mathrm{OH}$ radicals and the contaminants present in water. Thermodynamic mechanism which, by implosion of gas (air) bubbles developed in the low pressure phase, results in a very high pressure (a few hundred bar) and temperature (a few thousand ${ }^{\circ} \mathrm{C}$ ), thus creating conditions that cause cellular decomposition of microorganisms. Free radicals are generated in the same process. The third mechanism involves hydromechanical action (it manifests as a sudden multidirectional local movement of water), which results in a strong local sheer stress and breaking of the bond between the molecules, which is also caused by implosion of air bubbles [40]. One of the most important factors regarding ultrasound contamination removal efficiency is the frequency. An optimum frequency depends on the contamination and system geometry. High frequency will usually reduce cavitational effect because the negative pressure produced by the rarefaction cycle is insufficient in duration and/or intensity to initiate cavitation, and the compression cycle occurs faster than the time it takes for bubbles to collapse. At lower frequency, more violent cavitations will be produced, resulting in higher localized temperatures and pressure [4I]. 


\subsubsection{Electrocoagulation}

Electrochemical processes, such as electrochemical oxidation, electrochemical reduction, electrocoagulation (EC), electrocoagulation/flotation and electrodialysis, are usually used to remove pollution (or retrieve material) from highly contaminated wastewater by use of electricity and sacrificing electrodes. Electrocoagulation is usually used for water and wastewater treatment. It includes coagulation and precipitation of pollutants by the "in situ" coagulant production. Direct current is usually applied, while the use of electrodes and their characteristics (material and setup) depend on the wastewater pollution and the required quality of effluent. Several electrodes of the same material are usually used to form an electrode cell.

In the EC reactor, the water/wastewater flows between electrodes while the direct current is applied to them. The choice of the electrode material and their arrangement depends on the type of contaminants and the required quality of treated water. Aluminium (Al) is usually used for the drinking water treatment and iron ( $\mathrm{Fe})$ for the wastewater treatment. Aluminium and iron are relatively cheap and, compared to other metals, such as titan and silver, easily available, non-toxic, and proven effective [42], [43], [44], [45], [46].

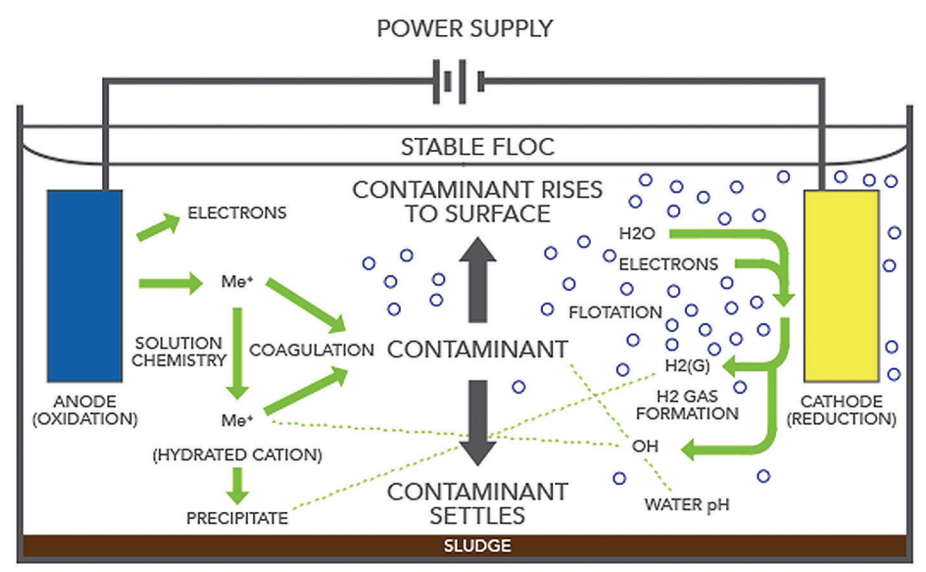

Figure 6. Electrochemical process in water treatment [6]

When the current is applied, metal hydroxides are produced in the reaction between either $\mathrm{A}^{3+}$ or $\mathrm{Fe}^{2+}$ ions, created in electrolytic oxidation of $\mathrm{Al}$ or $\mathrm{Fe}$ electrodes, and $\mathrm{OH}^{-}$ions from a reduction reaction taking place on the cathode where hydrogen gas is also released according to [47]:

$$
\begin{aligned}
& \mathrm{Fe}(\mathrm{s}) \rightarrow(\mathrm{Fe})^{2+}(\mathrm{aq})+2 \mathrm{e}^{-} \\
& \mathrm{Al}(\mathrm{s}) \rightarrow(\mathrm{Al})^{3+}(\mathrm{aq})+3 \mathrm{e}-
\end{aligned}
$$


$2 \mathrm{H}^{+}+2 \mathrm{e}^{-} \rightarrow \mathrm{H}_{2}(\mathrm{~g})$ (in acid medium)

$2 \mathrm{H}_{2} \mathrm{O}+2 \mathrm{e}^{-} \rightarrow \mathrm{H}_{2}(\mathrm{~g})+2 \mathrm{OH}^{-}$(in neutral or alkaline medium)

Metal hydroxides, used in the precipitation process, are produced according to the equations below [48]:

$$
\begin{aligned}
& 4 \mathrm{Fe}^{2+}(\mathrm{aq})+\mathrm{IOH}_{2} \mathrm{O}+\mathrm{O}_{2}(\mathrm{aq}) \rightarrow 4 \mathrm{Fe}(\mathrm{OH})_{3}(\mathrm{~s})+8 \mathrm{H}^{+} \\
& \mathrm{Fe}^{2+}(\mathrm{aq})+2 \mathrm{OH}^{-} \rightarrow \mathrm{Fe}(\mathrm{OH})_{2}(\mathrm{~s}) \\
& \mathrm{Al}^{3+}(\mathrm{aq})+\mathrm{nH}_{2} \mathrm{O} \rightarrow \mathrm{Al}(\mathrm{OH})_{\mathrm{n}}^{3-\mathrm{n}}+\mathrm{nH}^{+}
\end{aligned}
$$

Depending on the $\mathrm{pH}$ of wastewater and the oxidation potential, Fe can form divalent or trivalent cations, but $A l$ is only formed as a trivalent cation. These hydroxides trap colloidal particles and create flocs which can be easily removed from water by sedimentation or flotation [49]. The evolution of hydrogen bubbles leads to an increase in $\mathrm{pH}$ and it also helps flocculated particles to float out of the water [50]. There are various parameters affecting the efficiency of EC process for water/ wastewater treatment. Some of them are related to the operating conditions (current density, treatment time), others to wastewater characteristics ( $\mathrm{pH}$, conductivity), or to the geometry of EC reactor and electrodes setup (electrode size, polarization, electrode spacing) [46].These effects are usually case-specific and often differ between researches on small-scale and full-scale units (reactors). However, understanding the effects that process parameters have on the pollution removal efficiency will help in developing guidelines for the $\mathrm{EC}$ reactors design, and could lead to wider utilization of EC process.

Some of the advantages of the EC process are: effluent contains less total dissolved solids compared to other chemical processes; easy maintenance of the device; more efficient and faster degradation of organic matter compared to chemical coagulation; larger and more stable flocs are formed than those produced by chemical coagulation; it is not necessary to control the $\mathrm{pH}$ of the water, except in extreme cases; no chemicals are required; generated sludge has better quality and smaller volume (50 - $70 \%$ ) compared to chemical coagulation; several different types of pollutants can simultaneously be removed; side reactions, such as generation of hydrogen or hypochlorite, can be useful for the disinfection; it can be used as a decentralized system [45], [46], [5I], [52].

However, some of EC disadvantages are: electricity costs may be significant; possible passivation of anode due to oxygen presence and deposition on the cathodes; the electrodes need to be regularly replaced; high conductivity of wastewater is required; depending on the electrode material, high ion concentrations need to be removed from water; in some cases, gelatinous hydroxides may be dissolved in water; it is not effective for the removal of soluble substances such as ammonia, sugar, organic acids, solvents, phenols, alcohol and similar [45], [46], [5 I], [52]. 


\subsection{Numerical modelling}

The use of advanced computer technologies and tools, as well as the multi-criteria analysis and systems theory, are considered particularly useful in the sustainability analysis of different water systems [53].Thus, the functionality of, for example, water treatment processes can be improved through numerical modelling.

Water quality models simulate changes in contaminant concentration during its transport through the environment or reactor. Most reactions in purification processes occur in the form of multiphase processes. Typical examples are mixing of gaseous phase and water for the purpose of transmitting undesired contaminants or forming a solid phase that sink together with adsorbed contamination. There are a large number of reactors in which multi-stage processes with different transformation rates are taking place.

The continual modelling of different operational scenarios leads to an improved technology process, including the variability of the process itself over time.Therefore, phenomenological numerical models are based on the numerical integration of partial differential equations describing the process and its dynamics.

Basically, all purification processes contain the following mechanisms: water flow with pollution content, forcing of equilibrium states between water and gas or solid phase, transformation of the pollutant component into a gaseous or solid phase, degradation or die-off in water or solid phase and mass balance between liquid, gaseous and solid phases (continuity law).

Treatment of functionalities of the technological process can be monitored within a modelling environment such as Modelica (www.openmodelica.org) or Matlab / Simulink. Their implementation and simulation enables creation of a virtual water treatment plant that can be used not only by technologists, operating personnel and managers, but also for educational purposes, Figure 7.

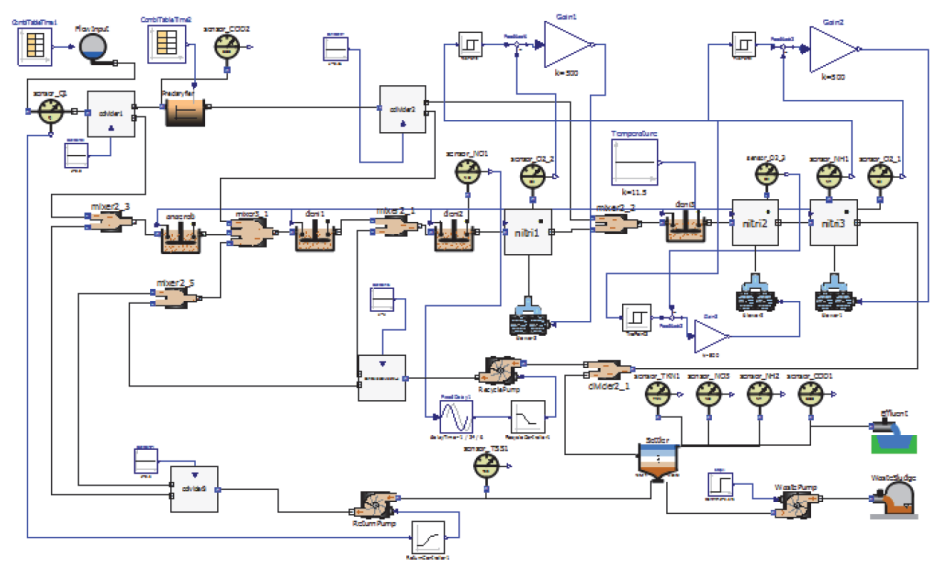

Figure 7.ASM3 example plant configuration in Modelica environment (municipal wastewater treatment plant with a size of I45 000 PE, [54]) 
Being part of the models developed in Matlab / Simulink and Modelica environment, partial differential equations are numerically integrated, and thus an insight can be gained into the time course of process development. Model libraries can be connected to each other, forming a complete technology line in purification process. In this way, it is easy to evaluate the effect of a particular process change on the overall effect of the applied technology scheme. Models are free to use, their structure and program routines are open and flexible, and they enable visualization of results [55].

Models for "real-time" optimization of technological processes take into account the perturbation of water flow and water quality. Thus the model has to have the following elements: robustness without changes in the original code, simple calibration based on "on-line" data from full-scale purification plant, corresponding graphical interpretation for comparing the measured and calculated values, the possibility of comparing different operating scenarios, evaluation of possible interaction between different parts of technological process, optimization criteria for the performance of an entire plant, a circuit that allows interaction with the control devices installed in the system.

Apart from stand-alone programs in different programming languages and welldeveloped programs for partial water treatment processes, there are also several software packages for simulation of complete water purification plants. The application of these programs enables users to diagnose the relationship between raw input water and process conditions, along with their optimization.

Otter (developed by WRc, UK). Modelling package designed to dynamically simulate performance of water treatment works [56]. The model can be used to simulate a particular purification process or complete installation in a water conditioning plant. The model describes the formation and elimination of a wide range of pollution parameters, from turbidity and colour to pesticides and microbiological indicators.

Metrex is being developed at the University of Duisburg/Germany [57]. In this model, simulations are carried out on the basis of analytical and numerical models of process steps usual in surface water treatment (microstraining, ozonation, floc formation, sedimentation, rapid filtration, granular activated carbon filtration, biodegradation, disinfection). The emphasis is on the removal of particle matter and ozonation (oxidation of dissolved organic carbon, iron and manganese, formation of bromate). Simulations are conducted in two levels. The first is an analysis of the entire process of purification in operational mode. In the second level, it is possible to change the concept and design an individual segment within the overall treatment process. This software package is based on the object-oriented model approach, using Java technology, the Internet and Matlab / Simulink.

The Water Treatment Plant (WTP) model was originally developed by the Environmental Protection Agency, in support of the Disinfectant/Disinfection By-products (D/DBP) Rule [58]. The model is based on empirical relationships recognized by regression analysis, and is focused on eliminating NOM, forming DBP and disinfection. The WTP model also enables the inclusion of laboratory analyses results and comparison with model simulation results (predictions). 
TAPWAT (Tool for the Analysis of the Production of drinking WATer) is elaborated by the Netherlands Institute of Public Health and the Environment (RIVM). The model is developed as a twofold model, through empirical and process modules. The modules are incorporated into one model structure and are commonly used for one particular application. The model respects the RIVM standard for information infrastructure and modelling [59].The main purpose of this model is to determine the likelihood of pathogenic microorganisms and DBPs coming out of the technological process.

On the other hand, fundamental research is usually focused on only one separate process. Generally, the aforementioned operating models are not adequate for describing all physico-biological-chemical phenomena that occur in complex interaction processes within each individual segment in the technological process of water conditioning.

The development of computers and software allows for more detailed modelling of process flows and substance detection through reactor circuits, also including the influence of hydraulics on physical, chemical and microbiological processes taking place in reactors. The application of the Computational Fuid Dynamics (CFD) has increased significantly nowadays, taking the leading role in research and optimization of hydraulic processes in a wide range of engineering applications. The use of CFD models (openFOAM,Ansys, COMSOL) enables prediction of flow fields and turbulent mixing to the various levels of detail.

A large number of studies have shown that CFD is a powerful tool for analysing and optimising particular water treatment processes, such as optimization of ozone contactors for microbial inactivation [60], [6I], disinfection performance of UV reactors [62], oxidation processes [63], investigation of electrochemical variables in the operation of a continuous upflow electrocoagulation process in treating textile wastewater [64], simulation of the grit and sand separation effectiveness of a typical hydrodynamic vortex separator (HDVS) system [65], simulation of mixing characteristics of a small circular anaerobic digester tank [66], working performance of closed-loop bioreactor [67][66], verification of compliance of a water reclamation plant disinfection stage with respect to modal time [68], or analysing efficiency of the electrocoagulation (EC) process with stainless-steel electrodes for total nitrogen removal [69].

The most challenging part is a reliable simulation of the flow field. Complex turbulent flow requires a detailed numerical modelling to detect all spatial and temporal turbulence scales, resulting in long and expensive calculations. Such DNS (direct numerical simulation) calculations are currently still unavailable for practical purposes. Simpler and satisfying accurate simulations rely on the so-called largeeddy simulation (LES) technique [70]. The use of LES still needs to be deployed with stronger computer resources, so the k-e turbulence model (RANS) is commonly used in engineering practice.The RANS (Reynolds averaged Navier-Stokes equations) models with the k-e turbulence model use an averaged flow field and adopt an "eddy viscosity" concept for describing fluctuating turbulent motion. The consequence of this simplification in RANS models is the reduced accuracy of simulation results in the vicinity of complex geometries. 
Experiments reliably determine characteristics of the flow field and biochemical parameters, while the CFD models give their predictions. Experiments are most often performed in laboratories and the results obtained are more reliable than the results of numerical simulations. Although relevant physical, biological and chemical processes are incorporated in the experiment itself, due to practical limitations, measurements are carried out with limited spatial and temporal resolution. Using the CFD model, it is possible to get insight into the characteristics of the process with the desired degree of resolution in the spatial and temporal domains. In addition, geometric modifications can be carried out relatively fast on numerical models, which is highly desirable, considering the usual needs for process optimization. Experiments are commonly expensive and time-consuming, while simulations with CFD models are relatively inexpensive, although they may last for a long time. However, despite the above mentioned benefits of the CFD model, it should be noted that numerical models adopt a whole set of assumptions and simplifications in turbulence field description and biochemical reactions. Therefore, experimental measurements are still necessary for better understanding of complex interaction in physical, biological and chemical processes, as well as for parameterization and validation of CFD models. Consequently, a combination of experimental and CFD tehniques is recommended for a more reliable recognition of complexity of technological processes. After the CFD model is validated for a specific technical installation, it can be used for energy consumption optimisation or for determining the required amount of chemicals.

\subsection{Implementation of green Infrastructure in urban drainage systems}

Increased temperatures and changes in global water cycles lead to temporal intensification of extreme rainfall events and changes in their spatial distribution, resulting in the flood risk increase from $10 \%$ to $170 \%$ [7I], [72]. In the EU alone. 32\% of all economic losses related to natural hazards is related to hydrological events such as floods and mass movements and approximately $20 \%$ of all cities in Europe are exposed to flood risk [73], [74], [75].The combined effect of climate change and urban population growth are main reasons of increased flood risk in urban areas around the world.According to latest UN projections, urban population will increase from current $55 \%$ to $68 \%$ in 2050 [74]. Urban floods can be divided, depending on the main drivers, into fluvial floods (from rivers), coastal floods (from extreme tidal conditions), and pluvial floods (surface water floods from heavy rains). Large urban areas and megacities exposed to combined impact of fluvial and tidal floods or fluvial and pluvial floods are especially vulnerable to flood risk, e.g. megacities in SE Asia [76], [77], [78].

Existing urban stormwater drainage systems are based on grey infrastructure elements that are designed to capture and pass excess water through the system of closed conduits (pipelines). Excess water is defined as a design storm for a given return probability, mostly of larger magnitude. These grey infrastructure elements are designed using mathematical hydrological-hydraulic models that offer a good level of 
predictability of the system behaviour, but the design is also based on the assumptions of invariability of once developed design storms and cannot capture changes in rainfall frequency and pattern due to the induced future climate changes. Urban drainage systems based on grey infrastructure additionally increase percentage of impermeable areas, which leads to excess water volume and increase in flood risk, but they are still irreplaceable for mitigating urban flooding from large-magnitude rainfall events. Negative effects on urban areas can also be caused by more frequent rainfall events of smaller magnitude, and modelling of different combinations of rainfall intensity and duration should therefore be examined.

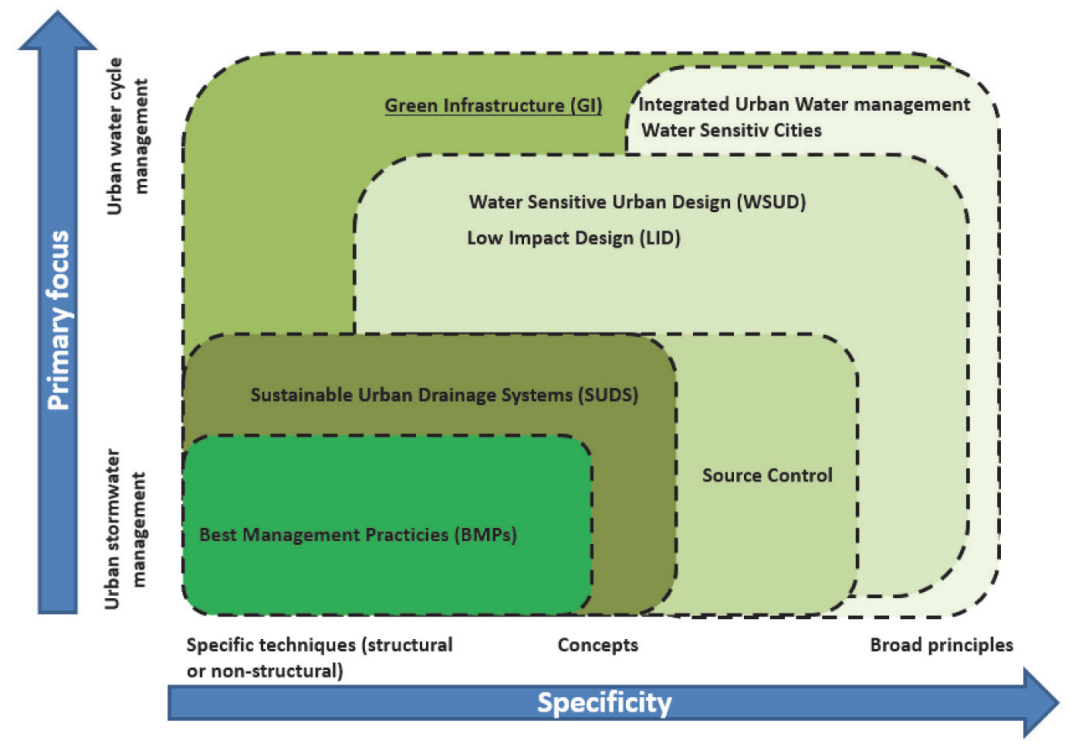

Figure 8. Evolution and application of terminology surrounding urban drainage adjusted from [79]

In order to face these challenges new, more effective, robust, and flexible solutions are used, such as those involving implementation of elements of Green Infrastructure (GI) into conventional urban drainage systems [79], [80]. Different terminology can be found in literature for these solutions depending on the part of the world, specificity, and their primary focus such as: SUDS Sustainable Urban Drainage Systems (SUDS), Runoff Best Management Practices (BMP), Low-Impact Development (LID), WaterSensitive Urban Design (WSUD), and Integrated Urban Water Management (IUWM) [79]. A schematic representation of these solution is given in Figure 7. It can be seen that the term Green Infrastructure covers a broad area, from specific techniques to broad principles, such as sustainable development. Incorporating SUDS techniques i.e. Gl elements such as: green roofs, wetlands, infiltration trenches, bioretentions, 
impervious pavements, rain gardens, etc., contributes to flood risk mitigation, and to microclimate and temperature control, but also improves water quality and biodiversity and amenities in urban areas. GI and SUDS contain both structural and non-structural measures [8I]. Numerous studies have confirmed benefits of implementation of the $\mathrm{GI}$ measures and techniques into urban drainage systems in newly developed areas and in existing urban areas. If these measures are appropriately applied, they can complement traditional urban drainage structures by reducing peak runoff, flood volume, and pollution load [82], [83], [84]. Guidelines for the design, construction and operation of urban drainage systems with $\mathrm{Gl}$ elements are available in [85] and [8I]. Average performance levels for various groups of elements can be found in Table I.

Table I. Performance level (H-high; M- medium; L-low) for various groups of SUDS techniques, i.e. GI elements, for improving water quality (WQ), hydraulic performance (HP) (based on runoff volume reduction (RVR) and flow rate control (FC)), maintenance and cost levels (M-C), and habitat creation potential (HCP).Adjusted from [8I]

\begin{tabular}{|c|c|c|c|c|c|c|}
\hline \multirow{2}{*}{$\begin{array}{l}\text { Element } \\
\text { groups }\end{array}$} & \multirow{2}{*}{$\begin{array}{l}\text { Examples of SUDS techniques, i.e. } \\
\text { GI elements }\end{array}$} & \multirow{2}{*}{ WQ } & \multicolumn{2}{|c|}{ HP } & \multirow{2}{*}{ M-C } & \multirow{2}{*}{ HCP } \\
\hline & & & RVR & FC & & \\
\hline Source control & $\begin{array}{l}\text { Green roof, Rainwater harvesting, } \\
\text { Pervious pavements }\end{array}$ & $\mathrm{L}-\mathrm{H}$ & $\mathrm{M}-\mathrm{H}$ & L-H & $\mathrm{H}$ & L-H \\
\hline Open channels & $\begin{array}{l}\text { Conveyance swale, Enhanced dry and } \\
\text { wet swales, Filter trench, Sand filters }\end{array}$ & $\mathrm{M}-\mathrm{H}$ & M & $\mathrm{H}$ & L-M & $\mathrm{M}-\mathrm{H}$ \\
\hline Filtration & $\begin{array}{l}\text { Surface sand filter, Bioretention/filter } \\
\text { strips }\end{array}$ & $\mathrm{H}$ & L & L-H & $\mathrm{M}-\mathrm{H}$ & L-M \\
\hline Infiltration & $\begin{array}{l}\text { Infiltration trench, Infiltration basin, } \\
\text { Soakaway }\end{array}$ & $\mathrm{H}$ & $\mathrm{H}$ & $\mathrm{H}$ & L-M & L-M \\
\hline Detention & Detention basin & L-M & L & $\mathrm{H}$ & L & $M$ \\
\hline Retention & Retention pond, Subsurface storage & L-M & $\mathrm{L}$ & $\mathrm{H}$ & M & $\mathrm{H}$ \\
\hline Wetland & $\begin{array}{l}\text { Shallow wetland, Extended detention } \\
\text { wetland, Pond/wetland, Wetland channel }\end{array}$ & $\mathrm{M}-\mathrm{H}$ & L & L-H & $\mathrm{H}$ & $\mathrm{H}$ \\
\hline
\end{tabular}

European Union encourages extension from the urban risk reduction approach towards the climate change adaption approach, with the final goal in the form of resilient and sustainable cities [86]. This is done through available legal framework including Water Framework Directive, Flood Directive, Climate Change Adjustment Strategy, Green Infrastructure Strategy, and the EU's Natural Disaster Strategy. The concept of sustainable water management in urban environments is explained and presented in literature from multiple aspects: engineering, economy, spatial planning, ecology [87], [88]. 


\subsection{Models and tools}

Models and tools for stormwater quality and quantity simulation, but also for their ability to incorporate $\mathrm{Gl}$ elements in urban drainage systems, have been reviewed by various authors [89], [90], [91], [92]. In most studies, the Storm Water Management Model (SWMM) developed by the United States Environmental Protection Agency (EPA) has been identified as the most sophisticated modelling tool from the aspect of accuracy, applied algorithms, and possibility for application in a wide range of spatial scales, from specific sites to catchment areas. In fact, the SWMM is the most popular freely available open source model for simulation of drainage systems with Gl practices such as: permeable pavements, rain gardens, green roofs, street planters, rain barrels, infiltration trenches, and vegetated swales [92], [93].

However, the Gl based solutions have certain disadvantages when compared to grey solutions. Perhaps the most notable one is the need for a larger surface area in urban environments where land is scarce and expensive. Therefore, it is important to have modelling tools for economic evaluation of conventional vs Gl solutions for urban stormwater management. Jayasoorija [92] has provided a detailed review of available ready-on modelling tools that can be used as simple design and/or decision making screening tools. This author specifies five tools that can address both the economic aspect and the stormwater quality and quantity aspect: (i) Centre for Neighbourhood Technology (CNT), Green Values National Stormwater Management Calculator; (ii) EPA System for Urban Stormwater Treatment and Analysis Integration Model (SUSTAIN); (iii) Model for Urban Stormwater Improvement Conceptualization (MUSIC); (iv) Low-Impact Development Rapid Assessment (LIDRA) and (v) Source Loading and Management Model for Windows (WinSLAMM).

Multitude of stakeholders with competing interests are involved in the design and management of urban drainage systems, which is why models need to be supported with decision-aid tools. The classification of decision-aid tools commonly used in sustainable drainage assessment for economic, social, environmental and health aspects of $\mathrm{Gl}$ is presented by Zhou in [9I]. The multi-criteria decision analysis (MCDA) approach is used for successful evaluation of trade-offs between different goals such as investment costs, and stormwater runoff quality and quantity. MCDA tools are used as an extension to existing models (e.g. SWMM- Software Toolkit for Research Involving Computational Heuristics (OSTRICH)) or as an integrated part of existing models (e.g. SUSTAIN) [93], [94], [95], [96].

Most evaluations of urban drainage systems overestimate economic and environmental benefits of $\mathrm{Gl}$ techniques and underestimate other benefits, social ones for instance. Namely, Gl provides, not only benefits connected with improvement of the urban water quality and quantity, but also other benefits that can be presented in the form of ecosystem services (ESS), such as improvement of air quality, reducing urban heat islands, improving resilience to climate change, pest and disease control, improving landscape, aesthetics, recreation, tourism, and cultural heritage aspects of urban areas, therefore improving overall wellbeing of inhabitants [97]. Effective incorporation of this approach into models enables evaluation of all direct and indirect benefits of 
$\mathrm{Gl}$, and an increase in investment opportunities and development of green economy. However, this step is still challenged by the development of indicators that can adequately present various aspects of ecosystem services [98], [99].

\subsection{Coastal Engineering}

Coastal engineering is a branch of civil engineering concerned with the construction at or near the sea coast where specific demands are imposed on the structure. Specific conditions are defined by the agency of wind waves, tidal oscillations, storm surges, tsunamis, and rough environment of salt seawater.

As to the future trends in coastal engineering, several influencing factors should be highlighted: I. development of CPU power, 2. rising of environmental awareness and climate change, 3 . an ever-growing database of easily accessible knowledge through the internet, 4. rising of image capture and processing technology and, finally, 5. artificial intelligence.

Ocean hydrodynamics is very complex due to interaction between several generators such as tidal oscillations, wind forcing, inertial characteristics of the water, etc. Such complex hydrodynamics has been for many years described by simplified mathematical models and an empirical approach. Thanks to the increasing CPU power of commercial computers, the complex hydrodynamics can be described using numerical models by modelling water movement in a more detailed manner.The main initiators of such trend are private companies who embed hydrodynamic numerical schemes in a friendly software environment suitable for engineering practice. Such trend will in the future lead to the situation where a complex interaction between the coastal structures and seawater will be described quite accurately, and will enable detailed design of shape, stability and functionality of structures.

The rising of environmental awareness has resulted in the situation where the civil engineering branch is increasingly faced with the challenges of construction with special care to nature. The optimisation between additional costs for environmental care and benefits from clean environment is a special issue of eco approach, and will in the future be the subject of significant scientific efforts. The care for nature is expressed through the reduction of $\mathrm{CO}_{2}$ emissions in construction works, discovery of new eco materials, and adoption of special approaches involving recycling, reuse and reduced use of materials.

The knowledge required for the design and construction of coastal structures is easily accessible through international web bases of scientific journals, and also through design codes and standards (such as Eurocode, US Corps of Engineers Coastal Engineering Manual, Australian standards, Japanese Standards etc.). This knowledge is not only easily accessible but is constantly growing through national and international research projects financed by private and state foundations. Future trends in civil engineering will lead to the production of expert software and expert systems based on this growing knowledge. The potential problem which will arise from such trend is separation of engineers and scientists from original methods, and excessive reliance on software as "black box" systems. 
Remote sensing and video capturing from air and land are a technology that is concerned with data acquisition and visualization [100]. New technology gives higher resolution, greater number of data and more frequent surveys, thus enabling better project planning and monitoring in the phase of construction and exploitation.

Artificial intelligence [ $\mathrm{IOI}$ ] influences not only technologies $\mathrm{n}$ civil engineering but is present in all aspects of human life. But the greatest influence is expected to occur in the field of construction through automation of works (navigation of trucks, cranes and floating cranes, navigation and automation of special floating equipment, control of the works, etc.).

\section{Conclusion}

The presented results of water body mapping, elevation model development, and actual evapotranspiration estimation, confirm that progress in hydrological and hydraulic modelling is closely linked with the progress in remote sensing techniques and methods. Hydroscience and engineering have seen application of remote sensing information and contemporary methods for a successful space-time monitoring of many other phenomena, such as discharge and surface water elevation, land and vegetation cover, rainfall and snowfall, sedimentation, snow depth, snow cover, and snow water equivalent, surface soil moisture, vegetation stress, etc.Advanced oxidation processes are especially considered as a highly competitive technology for water purification and removal of high chemical stability contaminants, because they do not demand the addition of other substances. Destruction of water contaminants occurs by thermal decomposition and various radical reactions. Although sonochemical processes have proven to oxidize various contaminants, the application of ultrasound is highly energy intensive and results in a very low electrical efficiency in comparison to other advanced oxidation-process technologies. Therefore, the coupling of ultrasound with other advanced oxidationprocess technologies has been receiving increased attention in recent years.

Computational Fluid Dynamics models have proven to be an inevitable tool in the process of disseminating knowledge and understanding hydrodynamic and biochemical processes in the water purification technology. Their proper application allows better design of particular reactor elements that are under significant hydrodynamic influence. Efforts in successful implementation of green infrastructure elements in urban drainage systems are currently going towards upgrading existing models and tools with new decision support systems based on artificial intelligence algorithms, and towards developing effective ecosystem services modules.

New technological innovations, digital solutions and availability of big data, artificial intelligence, together with non-technical innovations regarding social, cultural, ecological and institutional aspects, have opened up whole new areas of transdisciplinary research related to hydroscience. Further improvements and continuation of research and development, as well as fully operational application of hydrological-hydraulic models, are closely linked with the progress in accuracy and public availability of data used as input to simulate real-time conditions. 


\section{References}

[I] Guio-Torres, D.M.: Sustainability indicators for assessment of Urban Water Systems:The need for a common ground, First SWITCH Scientific Meeting, Birmingham UK, 2006.

[2] Chen, Z., Ngo, H. H., Gou, W.: A critical review on sustainability assessment of recycled water schemes, Science of the Total Environment, 426 (2012), pp. |3-3 I

[3] Carden, K., Armitage, N.P.:Assessing urban water sustainability in South Africa - not just performance measurement, Water SA, WISA Special Edition, 39 (2012) 3.

[4] Normalized diffenrence water index, https://www.sentinel-hub.com/eoproducts/ndwi-normalizeddifference-water-index, 20.06.2019.

[5] Courty, LG, Soriano-Monzalvo, JC, Pedrozo-Acuña, A: Evaluation of open-access global digital elevation models (AW3D30, SRTM, and ASTER) for flood modelling purposes, Journal of Flood Risk Management, 2019, doi: https://doi.org//0.1 II I/jfr3.12550

[6] Bekić, D., Mioč, A., Kerin, I.: 2D numerical simulations of 2012 flood wave passage through HPP system on the River Drava, Proceedings of the $13^{\text {th }}$ International Symposium on Water Management and Hydraulic Engineering, Bratislava: Slovak University of Technology, pp 5I-70, 2013.

[7] Ivezic, V., Bekic, D., Horvat, B.: Modelling of Basin Wide Daily Evapotranspiration with a Partial Integration of Remote Sensing Data, Atmosphere, 9 (2018) 120, doi: https://doi.org//0.3390/ atmos 9040120

[8] Nouri, H., Beecham, S., Kazemi, F., Hassanli, A.M., Anderson, S.: Remote sensing techniques for predicting evapotranspiration from mixed vegetated surfaces, Hydrology and Earth System Sciences, 2013 (10), pp 3897-3925.

[9] Ait-Mouheb, N. et al.:The reuse of reclaimed water for irrigation around the Mediterranean Rim: a step towards a more virtuous cycle, Regional Environmental Change, 18 (2018) 3, pp. 693-705, doi: 10.1007/s 10113-018-1292-z

[10] Gilja, G., Kuspilić, M., Vuković, Ž.: Trends in water use, $13^{\text {th }}$ International Symposium on Water Management and Hydraulic Engineering, Slovak University of Technology in Bratislava, Bratislava, Slovakia, pp. 425-434, 2013.

[II] Pistocchi, A. et al.: The potential of water reuse for agricultural irrigation in the EU, A HydroEconomic Analysis, Luxembourg, JRC 109870, 2018., doi: 10.2760/2637/3

[12] Poddar, K.,Vijayan, J., Ray, S., Adak, T.: Nanotechnology for Sustainable Agriculture, Biotechnology for Sustainable Agriculture: Emerging Approaches and Strategies, Woodhead Publishing, 2018, pp. 28I303, doi:10.1016/B978-0-12-812160-3.00010-6

[13] De Fraiture, C., Wichelns, D: Satisfying future water demands for agriculture, Agricultural Water Management, 97(2010)4, pp. 502-5I I, doi: https://doi.org/ /0.1016/j.agwat.2009.08.008

[14] Chartzoulakis, K., Bertaki, M.: Sustainable water management in agriculture under climate change, Agriculture and Agricultural Science Procedia, 4 (2015), pp. 88-98, doi: I0.1016/j.aaspro.20I5.03.0I I

[15] Velasco-Muñoz,J.F.,Aznar-Sánchez, J.A., Belmonte-Ureña, L.J., Román-Sánchez, I.M.:S Sustainable Water Use in Agriculture: A Review of Worldwide Research. Sustainability, 10 (2018) 4, pp. 1084, doi: 10.3390/sul0041084

[16] Singh, A.: Environmental problems of salinization and poor drainage in irrigated areas: Management through the mathematical models, Journal of Cleaner Production, 206 (2018), pp. 572-579, doi: 10.1016/j.jclepro.2018.09.21 I

[17] Singh,A.: Salinization of agricultural lands due to poor drainage:A viewpoint, Ecological Indicators, 95 (2018), pp. 127-130, doi: 10.1016/j.ecolind.2018.07.037

[18] Alvino,A., Marino, S.: Remote Sensing for Irrigation of Horticultural Crops, 3 (2017) 2, pp. 40

[19] Hadjimitsis, D.G., Papadavid, G., Themistokleous, K., Kounoudes, A., Toulios, L., Estimating irrigation demand using satellite remote sensing: a case study of Paphos District area in Cyprus, SPIE Remote Sensing, 7104 SPIE, 2008.

[20] Singh, A.: Managing the salinization and drainage problems of irrigated areas through remote sensing and GIS techniques, Ecological Indicators, 89 (2018), pp. 584-589, doi: 10.1016/j.ecolind.2018.02.04 I 
[2I] Ozdogan, M.,Yang,Y.,Allez, G., Cervantes, C.: Remote Sensing of Irrigated Agriculture, Opportunities and Challenges, 2 (2010)9, pp. 2274-2304.

[22] Calera, A., Campos, I., Osann, A., D'Urso, G., Menenti, M.: Remote Sensing for Crop Water Management, From ET Modelling to Services for the End Users, 17 (2017) 5, pp. II 04

[23] Tazekrit, I., Benslimane, M., Simonneaux, V., Hartani, T., Hamimed, A.: Estimation of Irrigation Water Pumping by Remote Sensing: Application of the SAMIR Model to Citrus under Mediterranean Climate Conditions, Journal Revista Brasileira de Meteorologia, 33 (2018),pp. $391-400$

[24] Dehni, A., Lounis, M.: Remote Sensing Techniques for Salt Affected Soil Mapping: Application to the Oran Region of Algeria, Procedia Engineering, 33 (2012), pp. 188-198, doi: https://doi.org/I0.1016/j. proeng.20I2.0I.II93

[25] Corbari, C., Salerno, R., Ceppi, A., Telesca, V., Mancini, M.: Smart irrigation forecast using satellite LANDSAT data and meteo-hydrological modelling,. Agricultural Water Management, 212 (2019), pp. 283-294, doi:10.1016/j.agwat.2018.09.005

[26] Berbić, J., Ocvirk, E., Gilja, G.: Comparison of supervised learning methods for prediction of monthly average flow. Građevinar, 70 (2018) 8, pp.643-656, doi::https://doi.org// 0.14256/JCE.2102.20I7

[27] Masseroni, D. et al.:Assessing the Reliability of Thermal and Optical Imaging Techniques for Detecting Crop Water Status under Different Nitrogen Levels, Sustainability, 9(2017) 9, pp. 1548, doi: I0.3390/ su9091548

[28] Liu,J., Pattey, E., Nolin, M.C., Miller,J.R., Ka, O.: Mapping within-field soil drainage using remote sensing, DEM and apparent soil electrical conductivity. Geoderma, I 43 (2008), pp. 26I-272, doi: I0.1016/j. geoderma.2007.II.0II

[29] Al-Saady, Y.I., Al-Suhail, Q.A., Al-Tawash, B.S., Othman, A.A.J.E.E.S.: Drainage network extraction and morphometric analysis using remote sensing and GIS mapping techniques (Lesser Zab River Basin Iraq and Iran), 75 (2016) 18, pp. 1243, doi: 10.1007/s 12665-016-6038-y

[30] Bekic, D., Halkijevic, I., Gilja, G., Loncar, G., Potocki, K., Carevic, D.,: Recent trends in environmental management systems driven by advanced technologies, Gradevinar, 7I (2019) 10, https://doi. org// $0.14256 /$ JCE.2728.2019

[3I] Do, M.T., Birkett, N.J., Johnson, K.C., Krewski, D., Villeneuve, P.: Canadian Cancer Registries Epidemiology Research Group: Chlorination disinfection by-products and pancreatic cancer risk, Environmental health perspectives, II 3 (2016) 4, pp. 4I8-424, doi: 10.1289/ehp.7403

[32] Mishra, B.K., Gupta, S.K., Sinha, A.: Human health risk analysis from disinfection by-products (DBPs) in drinking and bathing water of some Indian cities, Journal of environmental health science \& engineering, 12 (2014) 73, doi: 10.1 186/2052-336X-12-73

[33] Villanueva, C.M., Cordier, S., Font-Ribera, L. et al.: Overview of Disinfection By-products and Associated Health Effects, Curr Envir Health Rpt 2 (2015), pp. 107-15, doi: https://doi.org/10.1007/ s40572-014-0032-x

[34] Wang,J.L., Xu, L..: Advanced Oxidation Processes for Wastewater Treatment: Formation of Hydroxyl Radical and Application, Critical Reviews in Environmental Science and Technology, 42 (20I2) 3, $25 \mathrm{I}$ 325, DOI: 10.1080/10643389.2010.507698

[35] Son, Y.: Advanced Oxidation Processes Using Ultrasound Technology for Water and Wastewater Treatment, Handbook of Ultrasonics and Sonochemistry, Springer Science \& Business Media Singapore, 2015, doi: 10.1007/978-98I-287-470-2

[36] Petrier, C.; The use of power ultrasound for water treatment, Power Ultrasonics, Applications of High-Intensity Ultrasound, 2015, pp. 939-972, doi: I0.1016/B978-I-78242-028-6.0003 I-4

[37] CRS Electrocoagulation Technology, https://www.crs-reprocessing.com/en/crs-solutions/ electrocoagulation/, 20.03.2019.

[38] Ozturk E., Bal N.: Evaluation of ammonia-nitrogen removal efficiency from aqueous solutions by ultrasonic irradiation in short sonication periods, Ultrasonics Sonochemistry, 26 (20I5), pp. 422-427

[39] Juretić, H.: Advanced oxidation processes in the treatment of ships' ballast water, 2007., doctoral thesis, Faculty of Mechanical Engineering and Naval Architecture, Zagreb, Croatia

[40] Doosti, M.R., Kargar, R., Sayadi, M.H.: Water treatment using ultrasonic assistance: A review, Proceedings of the International Academy of Ecology and Environmental Sciences, 2 (2012) 2, pp. $96-110$ 
[4I] Matei, N., Scarpete, D.: Treatment of Wastewater by Ultrasound Intensity and Frequency Effect: A Review, ARPN Journal of Science and Technology, 5 (2015) II, pp. 59 I - 597

[42] Gardić,V::Primena elektrohemijskih metoda za prečišćavanje otpadnih voda, Deo I - elektrodepozicija i elektrokoagulacija, Zaštita meterijala, 48 (2007) I, pp. 49-58

[43] Chen, G., Hung, Y.: Electrochemical Wastewater Treatment Process, Advanced Physicochemical Treatment Technologies, 2007, pp. 57-I06, doi: I0.1007/978-I-59745-173-4_2

[44] Shammas, N.K., Pouet, M., Grasmick, A.: Wastewater Treatment by Electrocoagulation-Flotation, Flotation Technology, Wang, L., Eds., Springer: New York, NY, SAD, pp. 199-220, 2010.

[45] Kuokkanen,V., Kuokkanen T., Rämö, J., Lassi, U.: Recent Applications of Electrocoagulation in Treatment of Water and Wastewater - A Review, Green and Sustainable Chemistry, 8I (20I3) I, pp. 89-I2I

[46] Hakizimana, J.N., Gourich, B., Chafi, M., Stiriba, Y., Vial, C., Drogui, P., Naja, J.: Electrocoagulation process in water treatment:A review of electrocoagulation modelling approaches, Desalination, 404 (2017) I, pp.I-2I

[47] Naje,A.S., Abbas, S.A.: Electrocoagulation Technology in Wastewater Treatment:A review of Methods and Applications, Civil and Environmental Research 3 (2013), pp. 29-42

[48] Moussa, D.T., El-naas, M. H., Nasser, M.,Al-marri, M.J.:A comprehensive review of electrocoagulation for water treatment : Potentials and challenges, Journal of Environmental Management 2016, doi: 10.1016/j.jenvman.2016.10.032

[49] Pirkarami, A. and Olya, M.E.: Removal of dye from industrial wastewater with an emphasis on improving economic efficiency and degradation mechanism, Journal of Saudi Chemical Society, 21 (2017) I, pp. II76-II82

[50] Nandi, B.K., Patel, S.: Effects of operational parameters on the removal of brilliant green dye from aqueous solutions by electrocoagulation, Arabian Journal of Chemistry, I2 (2013) 2, pp. 296I-2968

[5।] Vepsäläinen, M.: Electrocoagulation in the treatment of industrial waters and wastewaters, Doctoral thesis, VTT technical research centre of Finland Itd., 2012.

[52] Marriaga-Cabarales, N. and Machuca- Martínez, F.: Fundamentals of electrocoagulation, Evaluation of Electrochemical Reactors as a New Way to Environmental Protection, Editors: Peralta-Hernández, J.M., Rodrigo-Rodrigo M.A., Martínez-Huitle, C.A., pp. I-16, 2014.

[53] Soroczynski, T., Integrated Systems Analysis and Sustainable Development, iEMSs 2002 Conference, Integrated Assessment and Decision Support, Lugano, Switzerland, pp. I33 - I38, 2002.

[54] Henze, M., Gujer, W., Mino, T., Loosdrecht, M.V.: Activated Sludge Models ASMI, ASM2, ASM2d, and ASM3, IWA Task Group on Mathematical Modelling for Design and Operation of Biological Wastewater Treatment, 2000.

[55] Helm, A.W.C., Rietveld, L.C.: Modelling of drinking water treatment processes within the Stimela Environment, Water Science and Technology:Water Supply, 2 (2002) I, pp. 87-93

[56] Head, R., Shepherd, D., Butt, G., Buck, G.: OTTER mathematical process simulation of potable water treatment, Water Science and Technology:Water Supply, 2 (2002) I, pp. 95-10I

[57] Mälzer, H.J., Nahrstedt, A.: Modellierung mehrstufiger Trinkwasseraufbereitungsanlagen mittels eines expertensystem-basierten Simulationsmodells (Metrex) am Beispiel von oberflächenwasser, IWW, 2002.

[58] Harrington, G.W., Chowdhury, Z.K., Owen, D.M.: Developing a computer model to simulate DBP formation during water treatment, Journal AWWA, 84 (1992) II, pp. 78-87

[59] Versteegh,J.F.M., Gaalen, F.W., Rietveld, L.C., Evers, E.G.,Aldenberg,T.A., Cleij, P.: TAPWAT: Definition, structure and applications for modelling drinking-water treatment, RIVM report 734301019, 2001.

[60] Li, J., Zhang, J., Miao, J., Ma, J., Dong, W.: Application of computational fluid dynamics (CFD) to ozone contactor optimization, Water Science and Technology:Water Supply, 6 (2006) 4, pp. 9-I6.

[6I] Zhang, J., Huck, P.M., Anderson, W.B., Stubley, G.D.: A computational fluid dynamics based integrated disinfection design approach for improvement of full-scale ozone contactor performance, Ozone: Science \& Engineering, 29 (2007) 6, pp. 45I-460

[62] Pan, H., Orava, M.: Performance evaluation of the UV disinfection reactors by CFD and uence simulations using a concept of disinfection efficiency, Journal of Water Supply: Research and Technology - AQUA, 56 (2007) 3, pp. 18I-189 
[63] Alpert, S.M., Knappe, D., Ducoste, J.:The use of computational fluid dynamics (CFD) to model UVinitiated advanced oxidation processes, 2007World Congress on Ozone and Ultraviolet Technologies, Los Angeles, 2007.

[64] Phalakornkule, C., Karakat, B., Nuyut,T., Ruttithiwapanich,T.: Investigation of Electrochemical Variables and Performance of a Continuous Upflow Electrocoagulation Process in the Treatment of Reactive Blue 140, Water Environment Research, 82 (2010) 12.

[65] Meroney, R.N., Sheker, R.E.: Removing Grit During Wastewater Treatment: CFD Analysis of HDVS Performance, Water Environment Research, 88 (2016) 5.

[66] Meroney, R.N., Sheker, R.E.: CFD Simulation of Vertical Linear Motion Mixing in Anaerobic Digester Tanks, Water Environment Research, 86 (2014) 9.

[67] Littleton, H.X., Daigger, G.T., Strom, P.F:: Application of Computational Fluid Dynamics to ClosedLoop Bioreactors: I. Characterization and Simulation of Fluid-Flow Pattern and Oxygen Transfer, Water Environment Research, 79 (2007) 6.

[68] Issakhanian, E., Saez, J.A., Helmns, A., Nickles, C.: Full simulation of disinfection stage in a water recycling plant using low-cost, hybrid 3-dimensional computational fluid dynamics, Water Environment Research, 91 (2019) 3, pp. I77-184

[69] Lončar,G.,Halkijević,I.,Posavčić,H.,Ban,l.:Modelling total-nitrogen dynamics during electrocoagulation process with stainless-steel electrodes, Electronic Journal of the Faculty of Civil Engineering Osijeke-GFOS, 16 (2018), pp. I I-23

[70] Moeng, C.: A large-eddy-simulation model for the study of planetary boundary-layer Turbulence, Journal of the Atmospheric Sciences, 4 I (1984) I3, pp. 2052-2062

[7I] Hettiarachchi, S.,Wasko, C., Sharma, A.: Increase in urban flood risk resulting from climate change The role of storm temporal patterns, Hydrology and Earth System Sciences Discussions, 22 (2017) 3, pp. 204I-2056, doi: 10.5194/hess-2017-352

[72] Wong T.H.F., Brown R.R.: The water sensitive city: principles for practice.Water Science \& Technology. 60 (2009) 3, pp: 673-682, doi: 10.2166/wst.2009.436

[73] European Environment Agency (EEA), Economic losses from climate-related extremes, https:// www.eea.europa.eu/data-and-maps/indicators/direct-losses-from-weather-disasters-3/assessment-I, 10.09.2018.

[74] European Environment Agency (EEA), Urban adaptation to climate change in Europe 2016 Transforming cities in a changing climate, EEA Report No 12/2016, https://www.eea.europa.eu/ publications/urban-adaptation-2016/at_download/file, 05.05.2019.

[75] United Nations (UN): Revision of World Urbanization Prospects, https://population.un.org/wup/, 05.05.2019.

[76] Apel, H., Trepat, O.M., Hung, N.N., Merz, B., Dung, N.V.: Combined fluvial and pluvial urban flood hazard analysis: concept development and application to Can Tho city, Mekong Delta, Vietnam, Natural Hazards \& Earth System Sciences, 16 (2016) 4, pp. 94I-96I, doi:I0.5 I 94/nhess-16-94I-2016

[77] Chan, F.K.S., Mitchell, G., Adekola, O., McDonald, A.: Flood Risk in Asia's Urban Mega-deltas: Drivers, Impacts and Response, Environment and Urbanization ASIA, 3 (20I2) I, pp. 4I-6I, doi: I0.1 I77/09754253 I200300I03

[78] Sang, Y.F., Yang, M.: Urban waterlogs control in China: more effective strategies and actions are needed, Natural Hazards, 85 (2017) 2, pp. I29|-I294, doi: 10.1007/s I 1069-0| 6-26 I4-4

[79] Casal-Campos, A., Fu, G., Butler, D., Moore, A.:An integrated environmental assessment of green and gray infrastructure strategies for robust decision making, Environmental science \& technology, 49 (2015) I4, pp. 8307-83।4, doi: 10.1021/es506I44f

[80] Fletcher, T. D., Shuster, W., Hunt, W. F., Ashley, R., Butler, D., Arthur, S., Mikkelsen, P. S. SUDS, LID, BMPs,WSUD et al.:The evolution and application of terminology surrounding urban drainage, Urban Water Journal, 12 (2015) 7, pp. 525-542, doi: 10.1080/I573062X.20I4.9163I4

[8I] Woods, B., R. Kellagher, P. Martin, C. Jefferies, R. Bray, Shaffer, P.: The SUDS manual (C697), CIRIA, London, UK, 2007.

[82] Martínez, C., Sanchez, A., Galindo, R., Mulugeta, A., Vojinovic, Z., Galvis, A.: Configuring green infrastructure for urban runoff and pollutant reduction using an optimal number of units, Water (Switzerland), 10 (2018) II, pp: I-20, doi: I0.3390/w I0III528 
[83] Liu, W., Chen, W., Peng, C.: Assessing the effectiveness of green infrastructures on urban flooding reduction: A community scale study, Ecological Modelling, 291 (2014) 10, pp. 6-14, doi: 10.1016/j. ecolmodel.2014.07.012

[84] Lucas, W.C., Sample, D.J.: Reducing combined sewer overflows by using outlet controls for Green Stormwater Infrastructure: Case study in Richmond, Virginia, Journal of Hydrology, 520 (2015), pp. 473-488, doi: 10.1016/j.jhydrol.2014.10.029

[85] Newton J., Gedge D., Early P.,Wilson S.: Building Greener, CIRIA report C644, 2007.

[86] EC-European Commission. "Green infrastructure (GI)-enhancing Europe's natural capital, European Commission, Brussels, 2013.

[87] Ashley, R., Garvin, S., Pasche, E., Vassilopoulos, A., Zevenbergen, C.: Advances in urban flood management, CRC Press, 2007.

[88] Wilderer, P.A.: Applying sustainable water management concepts in rural and urban areas: some thoughts about reasons, means and needs, Water Science and Technology, 49 (2004) 7, pp: 7-I6. doi: 10.2166/wst.2004.0403

[89] Zoppou, C.: Review of urban storm water models, Environmental Modelling \& Software, 16 (200I) 3, pp. 195-23I, doi: 10.1016/SI364-8152(00)00084-0

[90] Elliott, A.H., Trowsdale, S.A.: A review of models for low impact urban stormwater drainage, Environmental modelling \& software, 22 (2007) 3, pp: 394-405, doi: I0.10 I6/j.envsoft.2005. 12.005

[91] Zhou, Q.: A review of sustainable urban drainage systems considering the climate change and urbanization impacts, Water, 6 (2014) 4, pp. 976-992. doi: 10.3390/w6040976

[92] Jayasooriya, V.M., Ng, A.W.M.: Tools for modelling of stormwater management and economics of green infrastructure practices: A review, Water, Air and Soil Pollution, 225 (2014) 2055, doi: 10.1007/ sI |270-0|4-2055-I

[93] Macro, K., Matott, L.S., Rabideau, A., Ghodsi, S. H., Zhu, Z.: OSTRICH-SWMM:A new multi-objective optimization tool for green infrastructure planning with SWMM, Environmental Modelling \& Software, II3 (2019), pp. 42-47, doi: 10.1016/j.envsoft.2018.12.004

[94] Figueira, J., Greco, S., Ehrgott, M.: Multiple criteria decision analysis: state of the art surveys, Springer Science \& Business Media, 78 (2005).

[95] Lai, E., Lundie, S., Ashbolt, N.J.: Review of multi-criteria decision aid for integrated sustainability assessment of urban water systems, Urban water journal, 5 (2008) 4, Pp. 315-327, doi: 10.1080/1573062080204/038

[96] Kabir, G., Sadiq, R., Tesfamariam, S.: A review of multi-criteria decision-making methods for infrastructure management, Structure and Infrastructure Engineering, 10 (2014) 9, pp. II76-12 I0, doi: 10.1080/15732479.2013.795978

[97] Millennium Ecosystem Assessment: Ecosystems and Human Well-Being: Synthesis, Island Press, Washington, DC, USA, 2005.

[98] Vojinovic, Z., Keerakamolchai,W.,Weesakul, S., Pudar, R., Medina, N.,Alves, A.: Combining Ecosystem Services with Cost-Benefit Analysis for Selection of Green and Grey Infrastructure for Flood Protection in a Cultural Setting, Environments, 4(2016) I, doi: I0.3390/environments40I0003

[99] Eggimann, S., Mutzner, L., Wani, O., Schneider, M. Y., Spuhler, D., Moy de Vitry, M., Maurer, M.: The potential of knowing more:A review of data-driven urban water management, Environmental science \& technology, 5 I (20I7)5, pp. 2538-2553, doi: 10.102I/acs.est.6b04267

[100] Bartolini, B., Mecocci,A., Pozzebon, A., Zoppetti, C., Bertoni, D., Sarti, G., Caiti,A., Costanzi, R., Catani, F., Ciampalini, A., Moretti, S.:Augmented Virtuality for Coastal Management:A Holistic Use of In Situ and Remote Sensing for Large Scale Definition of Coastal Dynamics, ISPRS International Journal of Geo-Information 7 (2018) 3, doi:I0.3390/ijgi7030092

[I0I] Lu, P, Shengyong, C., Zheng, Y.: Artificial Intelligence in Civil Engineering, Mathematical Problems in Engineering, 20I2, doi:I0.I I55/20I2/I45974 